\title{
Duboka mozgovna stimulacija - prijeoperacijska priprema i procjena pacijenata s Parkinsonovom bolešću
}

\section{Deep brain stimulation - preoperative preparation and evaluation of patients with Parkinson's disease}

\author{
Kristina Kampić ${ }^{*}$, Vladimira Vuletić1,2, Darko Chudy ${ }^{3}$
}

${ }^{1}$ Klinika za neurologiju, Klinički bolnički centar Rijeka, Rijeka, Hrvatska

${ }^{2}$ Sveučilište u Rijeci, Medicinski fakultet, Rijeka, Hrvatska

${ }^{3}$ Zavod za neurokirurgiju, Klinička bolnica Dubrava, Zagreb, Hrvatska
Sažetak. Parkinsonova bolest druga je najučestalija neurodegenerativna bolest. Najčešći simptomi pacijenata koji boluju od Parkinsonove bolesti su tremor u mirovanju, rigidnost, bradikinezija i poremećaj hoda. Liječenje Parkinsonove bolesti složeno je. Razlog tome je kompleksnost bolesti te dugogodišnja progresija. Liječenje može biti medikamentozno ili invazivnim metodama liječenja poput duboke mozgovne stimulacije. Kod medikamentoznog liječenja koristimo tri kategorije lijekova. Prva kategorija lijekova povećava razinu dopamina u mozgu, druga kategorija lijekova, kao što su antikolinergički lijekovi, smanjuje simptome Parkinsonove bolesti i treća kategorija djeluje na nemotoričke simptome Parkinsonove bolesti. Ako medikamentozno liječenje nije dostatno, danas se najviše primjenjuje duboka mozgovna stimulacija. Duboka mozgovna stimulacija je neurokirurška intervencija kojom se ugrađuje elektroda u područje subtalamičke jezgre, ventralne intermedijalne jezgre ili u područje globus pallidus, jer se motoričke komplikacije Parkinsonove bolesti ne mogu adekvatno kupirati lijekovima. Prije same neurokirurške intervencije važna je prijeoperacijska priprema i procjena pacijenata koji su potencijalni kandidati za ovakav zahvat. U prijeoperacijskoj pripremi $\mathrm{i}$ procjeni pacijenata treba sudjelovati multidisciplinarni tim stručnjaka koji uključuje psihologe, psihijatre, neurokirurge, a posebnu ulogu imaju kliničari, neurolozi, koji svoje pacijente najbolje poznaju te mogu procijeniti daljnju kvalitetu života pacijenta nakon ugradnje DBS-a.

Ključne riječi: duboka mozgovna stimulacija; Parkinsonova bolest; terapija

Abstract. Parkinson's disease is the second most common neurodegenrative disease. The most common symptoms of patients with Parkinson's disease are rest tremor, rigidity, bradykinesia and gait disorder. The treatment of Parkinson's disease is very complex. The reason for this is disease's complexity and yearly progression. It can be medicamentous therapy or invasive methods like applying deep brain stimulation (DBS). There are three categories of medicamentous therapy that are used. The first category of drugs increases the level of dopamine in the brain, the second category of drugs reduces the symptoms of Parkinson's disease, such as anticholinergic drugs and the third category of drugs is used for non-motor symptoms of Parkinson's disease. If medicamentous therapy is not sufficient, deep brain stimulation is used today. Deep brain stimulation is the neurosurgical procedure involving the placement an electrode into the area of the subthalamic nucleus, ventral intermediate nucleus (VIM) in thalamus or globus pallidus because the motor complications of Parkinson's disease can not be adequately eliminated with drugs. Before the neurosurgical procedure, the preoperative preparation and evaluation of the patients, who are potential candidates for this procedure, is very important. A complete medical evaluation is necessary for the preoperative preparation of patients. The preoperative preparation and evaluation of patients should involve a multidisciplinary team of experts including psychologists, psychiatrists, neurosurgeons, with a special role for clinicians, neurologists, who know their patients best and can evaluate the patients' further quality of life after DBS is installed.

Key words: deep brain stimulation; Parkinson's disease; therapy 


\section{UVOD}

Parkinsonova bolest (PB) druga je najučestalija progresivna neurodegenerativna bolest odmah iza Alzheimerove bolesti ( $A B)$ koja zahvaća višestruke neurotransmiterske moždane puteve, a posebno dopaminski nigrostrijatalni put. U Sjedinjenim Američkim Državama preko milijun ljudi boluje od Parkinsonove bolesti, a smatra se da u svijetu postoji više od deset milijuna ljudi koji boluju od iste bolesti. Parkinsonova bolest zahvaća i muškarce i žene neovisno o rasi i podrijetlu osobe. Srednja dob pojavnosti Parkinsonove bolesti je oko 60 godina života, međutim, postoje i slučajevi gdje se Parkinsonova bolest pojavila u osoba s 20 godina i manje. Učestalost pojavnosti Parkinsonove bolesti povećava se $s$ godinama, te se smatra da će se prevalencija drastično povećati i u budućnosti, s obzirom na to kako se i životni vijek čovjeka produžio. Osim liječenja ove bolesti, problem koji se javlja je upravo narušena kvaliteta života osobe oboljele od Parkinsonove bolesti ${ }^{1}$. Kliničke karakteristike Parkinsonove bolesti su tremor u mirovanju, rigidnost, bradikinezija i poremećaj hoda, poznatiji kao „kardinalni simptomi“ Parkinsonove bolesti. Posturalna nestabilnost, „zamrzavanje“ u hodu, poteškoće govora, autonomni poremećaji, senzorički poremećaji, poremećaji raspoloženja i spavanja, demencija te kognitivni poremećaji poznatiji su kao nedopaminergični simptomi ili tzv. „dodatni simptomi“ Parkinsonove bolesti. Dijagnoza same Parkinsonove bolesti temelji se na prezentaciji motoričkih deficita koji su ranije navedeni. Sam motorički deficit ujedno je i predominantno konsekvenca gubitka dopaminergičkih neurona u supstanciji nigri te se i sama simptomatska terapija Parkinsonove bolesti temelji na strategiji nadomještanja manjka dopamina $^{1}$. Nemotorički simptomi Parkinsonove bolesti koji mogu započeti i prije pojave samih motoričkih simptoma najčešće su hiposmija ili anosmija (90\% pacijenata), poremećaji REM faze spavanja, depresija (35\% pacijenata) i konstipacija (25 - $67 \%$ pacijenata) te se ti simptomi najčešće javljaju nekoliko godina prije pojave motoričkih simptoma i dijagnosticiranja same bolesti. Upravo ti simptomi smatraju se simptomima prodromalne faze Parkinsonove bolesti te su mogući budući biomarkeri za ranije otkrivanje
Parkinsonove bolesti. Smatra se da upravo nemotorički simptomi Parkinsonove bolesti ukazuju i na težinu same bolesti, točnije, što je više nemotoričkih simptoma Parkinsonove bolesti, to je i sama bolest teža, što ujedno utječe na kvalitetu života pacijenata u vidu otežavanja liječenja bolesti i skraćenja životnog vijeka pacijenata².

U mnogobrojnim simptomima, što motoričkim, što nemotoričkim, jedan simptom Parkinsonove bolesti često se zaboravlja, a to je simptom bola. Važno je naglasiti kako postoji kod osoba obolje-

Napredovanjem bolesti primjena lijekova nije dostatna i ne može kontrolirati diskinezije te se u tom slučaju može primijeniti duboka moždana stimulacija (DBS). DBS je vrsta operacije mozga kod koje se tanka, izoliarana žica (elektroda) postavlja duboko u mozak u području subtalamičke jezgre, ventralne intermedijalne jezgre (VIM) ili području globus pallidus.

lih od ove bolesti pet različitih vrsta bola: muskuloskeletni bol uzrokovan rigidnošću, a i reumatološkim bolestima koje se često javljaju u sklopu Parkinsonove bolesti, kao i skeletna deformacija; radikularni neuropatski bol, najčešće nastao lezijom korijena živca, žarišna ili periferna neuropatija; distonični bol i centralni neuropatski bol, najčešće uzrokovan antiparkinsonicima; akatizija koja nastaje u „OFF“ fazi ili je uzrokovana lijekovima. Prevalencija bola u Parkisonovoj bolesti je između 68 i $85 \%{ }^{3,4}$.

U 85 - 90 \% slučajeva Parkinsonova bolest javlja se sporadično, bez jasnog uzroka. Twin studije sugeriraju kako čimbenici okoliša i način života više utječu na pacijente iznad 50 godina života, međutim, niti jedan konkretan čimbenik okoliša nije u potpunosti dokazan kao uzrok Parkinsonove bolesti. Kod mlađih pacijenata smatra se kako je bitnija genetska uloga i nasljeđivanje. Patofiziološkim poremećajem koji se javlja kod Parkinsonove bolesti prvenstveno je zahvaćena substantia nigra. Neuroni tog područja mozga zaduženi su za proizvodnju dopamina. Dopamin je kemijski glasnik zadužen za prijenos signala između supstancije nigre i sljedeće stanice corpus striatum u stvaranju učinkovitog i glatkog pokreta. Poremećaji i oštećenja koja se u tom području dogode 
dovode do lošeg prijenosa ili nemogućnosti prijenosa signala, što rezultira nevoljnim i neučinkovitim pokretima, što u krajnjem rezultatu dovodi do nastanka motoričkih simptoma Parkinsonove bolesti ${ }^{5}$.

Liječenje Parkinsonove bolesti može biti medikamentozno ili u uznapredovalim fazama invazivnim metodama, poput primjene duboke mozgovne stimulacije. Lijekovi za liječenje Parkinsonove bolesti dijele se u tri kategorije. Prva kategorija lijekova su oni koji povećavaju razinu dopamina u mozgu, kao što je prekursor dopamina - levodopa koja prelazi krvno-moždanu barijeru i pretvara se u dopamin. Druga kategorija lijekova su oni koji se koriste za smanjivanje simptoma bolesti, kao što su antikolinergički lijekovi, koji ometaju proizvodnju ili unos acetilkolina. Takvi lijekovi najviše utječu na reduciranje tremora. Treća kategorija lijekova su oni koji utječu na nemotoričke simptome, poput depresije, te se osobama koje boluju od Parkinsonove bolesti mogu propisivati. Napredovanjem bolesti primjena lijekova nije dostatna i ne mogu se kontrolirati diskinezije i nemotorički simptomi, u tom se slučaju može razmišljati o primjeni duboke mozgovne stimulacije (DBS). DBS je vrsta neurokirurške operacije mozga kod koje se tanka, izolirana žica (elektroda) postavlja duboko u mozak u području subtalamičke jezgre, ventralne intermedijalne jezgre (VIM) ili u područje globus pallidus. Elektroda je spojena na uređaj sličan srčanom elektrostimulatoru „pacemakeru“ koji se nalazi ispod ključne kosti prsnog koša. Uređaj šalje impulse koji bezbolno stimuliraju mozak te time „uklanjaju“ motoričke i nemotoričke simptome Parkinsonove bolesti. Uporabu DBS-a odobrila je Američka uprava za hranu i lijekove i definirane su jasne indikacije i kontraindikacije kod Parkinsonove bolesti ${ }^{5,6}$.

\section{DUBOKA MOZGOVNA STIMULACIJA} (ENGL. DEEP BRAIN STIMULATION - DBS)

Duboka mozgovna stimulacija je neurokirurška intervencija koja se primjenjuje kada se motoričke i nemotoričke komplikacije Parkinsonove bolesti ne mogu adekvatno kupirati lijekovima. Posljednjih nekoliko desetljeća kod više od 100 000 pacijenata oboljelih od Parkinsonove bolesti poboljšana je kvaliteta života upravo smanjivanjem motoričkih i nemotoričkih simptoma Parkinsonove bolesti primjenom duboke mozgovne stimulacije. Novija istraživanja pokazuju kako je duboka mozgovna stimulacija pokazala veliku korist i u drugim neurološkim, a i psihijatrijskim bolestima, te se sada indicira kod pacijenata $s$ kroničnim bolom, posttraumatskog stresnog poremećaja, opsesivno-kompulzivnog poremećaja, distonije, tremora itd. lako sad već možemo govoriti o povijesti korištenja DBS metode, još uvijek nije jasan princip i mehanizam djelovanja ovog vida terapije. Istraživanja u tijeku ističu kako bi trebalo pacijente koji koriste terapiju duboke mozgovne stimulacije pratiti funkcionalnom pretragom magnetske rezonancije te time utvrđivati učinak terapije. Ako se takav pristup pokaže učinkovitim, pacijente koji koriste ovakav vid terapije bilo bi lakše pratiti, što podrazumijeva i lakše liječenje ${ }^{7}$.

Idealni kandidati za primjenu duboke mozgovne stimulacije kod Parkinsonove bolesti su pacijenti koji imaju fluktuirajuće motoričke simptome ili štetne učinke koji se povezuju s dosadašnjom terapijom. Pacijent nakon medikamentozne terapije može primijetiti kako doza nije dovoljna do primjene sljedeće doze medikamentozne terapije, tzv. „wearing-off“ ili trošenje. Kad se lijek „potroši" simptomi Parkinsonove bolesti, kao što su tremor, usporenost, teškoće u hodu, mogu se ponovno pojaviti u težem obliku. Nakon ponovne primijene dosadašnjeg lijeka simptomi se poboljšavaju. Razdoblje u kojem imamo dobar učinak lijeka zove se „ON“ razdoblje, a razdoblje kada lijek prestaje djelovati te dolazi do pogoršanja simptoma zove se „OFF“. Kada se kod pacijenta više ne može regulirati „ON“ i „OFF“ razdoblja samo medikamentoznom terapijom, može se primijeniti duboka mozgovna stimulacija. Duboka mozgovna stimulacija najčešće se primjenjuje obostrano, a vrlo rijetko jednostrano. Unatoč činjenici kako je DBS neurokirurška metoda, smatra se sigurnim postupkom, a većina nuspojava koje se pojavljuju nakon ugradnje DBS-a su blage i privremene. Randomizirano kontrolirala studija objavljena 2009. godine govori u prilog tome kako pacijenti kod kojih je primijenjena duboka mozgovna stimulacija koji su u prosjeku bili stimulirani 4,5 sati 
na dan, za razliku od pacijenata koji su primali najbolju medikamentoznu terapiju, imaju statistički značajno $(p<.001)$ poboljšanje motoričkih simptoma. $71 \%$ pacijenata koji su kao terapiju koristili DBS za razliku od 32 \% pacijenata na najboljoj medikamentoznoj terapiji imali su klinička značajna poboljšanja motoričke funkcije ${ }^{7,8}$.

Do sada se nije toliko poklanjalo pažnju korištenju DBS-a za liječenje nemotoričkih simptoma, ali treba istaknuti kako najnovija istraživanja pokazuju veliku korist DBS-a kod nekih psihijatrijskih simptoma koji se javljaju u sklopu Parkinsonove bolest i spadaju u nemotoričke simptome. Ako pacijent ima psihotične simptome ili tešku depresiju, nije kandidat za postavljanje DBS-a. Osim liječenja psihijatrijskih simptoma koje se javljaju u Parkinsonovoj bolesti, istraživanje skupine američkih znanstvenika iz 2019. godine govori u prilog tome kako se upravo DBS metodom idealni rezultati postižu kod pacijenata koji boluju od Parkinsonove bolesti, a jedan od vodećih nemotoričkih simptoma im je kronični bol. Mehanizam uklanjanja bola dubokom mozgovnom stimulacijom nije poznat, niti dovoljno istražen, a ono što pokazuje istraživanje je kako se bol unatoč primjeni DBS-metode ipak ponovno javi nakon 8 godina od ugradnje ${ }^{9}$.

\section{ODABIR PACIJENATA ZA DUBOKU} MOZGOVNU STIMULACIJU

Odabiru pacijenata za duboku mozgovnu stimulaciju moramo pristupiti kritički, jer se radi o invazivnoj metodi, a i o tome ovisi uspjeh i učinkovitost implantacije. lako su komplikacije samog zahvata minimalne, uvijek treba misliti na kirurški morbiditet i smrtnost, kratkoročne i dugoročne troškove koje nosi DBS, uloženo vrijeme i napore medicinskog osoblja i obitelji prilikom prilagođavanja na novi vid terapije i korekciju stare terapije, praćenja potencijalnih komplikacija vezanih za sam uređaj te također ograničeni broj kirurškog medicinskog osoblja koje je educirano za njegovo postavljanje. Kako bi korist ovakvog zahvata i terapije bila što veća, potrebno je razmotriti određene stavke kao što su: koji pacijenti bi imali najveću korist od ove terapije, koji će zadržati tu korist dovoljno dugo vremena kako bi uloženo bilo i opravdano te koji su pacijenti fizički i kognitivno sposobni podnijeti operacijske protokole prije i poslije zahvata i prilagodbu na uređaj i novu terapiju. Kod postavljanja indikacije za DBS ponajprije se gleda njihov odgovor na levodopu levodopa testom. Ako je levodopa test zadovoljavajući, a pacijenti unatoč maksimalno tolerirajućim dozama i polivalentnoj dostupnoj terapiji antiparkinsonicima nemaju dobro kontrolirane simptome (posebno „OFF“ razdoblja i fluktuirajuće motoričke simptome), smatraju se potencijalnima za DBS. Lakše podnošenje svih operacijskih protokola prije i poslije zahvata najviše i najčešće u korist ide mlađim pacijentima, međutim, sam DBS najčešće je potreban starijim pacijentima kod kojih sama terapija levodopom nije dostatna kupirati simptome. Kod svih je pacijenata, a posebno kod starijih, bitna procjena fizičke i kognitivne funkcije te drugih komorbiditeta prije implantacije uređaja. Ono što je bitno naglasiti je da većina znanstvenika koja proučava Parkinsonovu bolest i terapiju DBS-om smatra kako sam „uključni“ kriteriji za isto moraju biti pacijenti koji imaju isključivo idiopatsku Parkinsonovu bolest. Znanstvenici smatraju kako je već odgovor na levodopu (levodopa test) dovoljan za pretpostavku koliki će biti učinak i koliko dugo će odgovor na terapiju DBS-om potrajati, međutim, bitan je i prirodan tijek bolesti zbog mogućeg razvoja levodoparezistentnih simptoma, posebno tzv. aksijalnih simptoma Parkinsonove bolesti za koje se zna da slabije reagiraju na DBS terapiju, tj. danas odabranim i znanim ciljnim mjestima implantacije. Osobito je bitno sa sigurnošću postaviti dijagnozu idiopatske Parkinsonove bolesti, kako se ne bi radilo o nekoj vrsti atipičnog parkinsonizma, poput multiple sistemske atrofije (engl. multiple system atrophy - MSA) kod koje odgovor na levodopu i DBS terapiju kratkoročno može biti jako dobar, više nego zadovoljavajući, ali ta bolest puno brže napreduje i ranije se pojavljuju levodoparezistentni simptomi nego kod idiopatske Parkinsonove bolesti, što dovodi do zaključka kako korist i primjena DBS-metode u tom slučaju nije bila opravdana. Istraživanja su pokazala kako se i nakon primijene DBS-a pacijente treba pratiti i bilježiti ishod te se kod pojedinih pacijenata tek obostrana duboka mozgovna stimulacija uz primjenu lijekova pokazala korisnom, gdje su „OFF“ 
razdoblja i ostale motoričke fluktuacije gotovo u potpunosti nestale. Još uvijek je u fazi istraživanja korist DBS-a kod pacijenata koji imaju mutaciju gena PRKN koji je zadužen za stvaranje proteina parkin. Ono što su do sada istraživanja pokazala je to da pacijenti koji imaju mutaciju tog gena i DBS terapiju za sada pokazuju dobar odgovor na DBS te se smatra kako kod tih pacijenata treba indicirati DBS i nastaviti bilježiti rezultate. Posljednji kriteriji za odabir pacijenata koji treba istaknuti je mogućnost podnošenja relativno dugotrajnog $\mathrm{i}$

Često u procjeni uz neurologa i neurokirurga trebamo mišljenja psihologa, psihijatra, logopeda, fizijatra i fizioterapeuta. Ono što je najbitnije je dobra procjena koju daje multidisciplinarni tim, koja obuhvaća procjenu motoričkih i nemotoričkih simptoma kod pacijenta te komorbiditeta koji mogu prevladati korist samog DBS-a.

zahtjevnog operacijskog zahvata implantiranja samog uređaja, gdje bi sam pacijent trebao biti suradljiv i fizički sposoban tolerirati takvu vrstu operacije, što je često nemoguće za starije i oslabljene pacijente s brojnim komorbiditetima, kao što su različite kardiopulmonalne bolesti, a nakon operacije i cijeli proces prilagodbe na novi vid terapije. Simptomatologija akutnih psihijatrijskih bolesti u sklopu Parkinsonove bolesti, na koje još uvijek DBS nema konkretan odgovor i demencija, smatraju se kontraindikacijom za DBS ${ }^{10}$.

\section{ZAŠTO JE VAŽAN DOBAR ODABIR}

\section{PACIJENATA ZA DBS?}

Dokazi utvrđeni istraživanjima ukazuju na to da se od samog početka za oko $30 \%$ pacijenata kod kojih se DBS metoda smatra neuspjehom može reći da su „loši“ kandidati za DBS, što sugerira na značajne varijacije liječničkog razumijevanja indikacija za DBS ${ }^{11}$. Ujedno se smatra da zbog toga pojedini kandidati koji bi potencijalno imali koristi od DBS metode nisu izabrani za isti vid liječenja. $S$ obzirom na to kako se DBS počinje primjenjivati $\mathrm{i}$ u drugim bolestima, poput raznih psihijatrijskih bolesti, krucijalnim se smatralo osigurati edukaciju liječnika za bolje razumijevanje indikacija DBS-a. U počecima korištenja DBS-a kao metode u liječenju idiopatske Parkinsonove bolesti istraži- vanja pokazuju kako je svega 4,5 \% odabranih pacijenata bilo prikladno za primjenu te metode ${ }^{11}$. Rezultati tih istraživanja izašli su svega dvije godine nakon što je korištenje DBS metode odobrila Uprava za hranu i lijekove, a taj se postotak edukacijom liječnika povećao i sve se više povećava. ${ }^{11}$ Australski znanstvenici 2009. godine objavili su rad u kojem iznose smjernice za odabir pacijenata. Cilj tih smjernica je, kao i danas, pomoći neurolozima i drugim liječnicima, posebno DBS timu, u identifikaciji pacijenata kojima bi upućivanje na DBS moglo koristiti ${ }^{12}$.

Početni neselektivan odabir pacijenata zbog nedovoljne edukacije liječnika za korištenje DBS metode dovodio je do čestih komplikacija koje su se vezale uz korištenje DBS-a. Daljnja istraživanja, edukacije, smjernice te zajednička suradnja DBS timova povećavali su broj uspješnosti postavljanja DBS-a, dugotrajnost liječenja i zadovoljstvo samih korisnika, a sam postotak dobro odabranih pacijenata povećao $\mathrm{se}^{13}$.

PRIJEOPERACIJSKA PRIPREMA I PROCJENA PACIJENATA ZA DBS

Unatoč koristi ove metode kod velikog broja pacijenata, jako puno kriterija i čimbenika mora biti uzeto u obzir prilikom obrade, odabira i prijeoperacijske pripreme pacijenata za DBS. Neki od najvažnijih čimbenika su dob, prisutnost drugih komorbiditeta, odgovor na levodopu, dužina trajanja bolesti, tip Parkinsonove bolesti i simptomi same bolesti. Neuropsihijatrijska i neuropsihološka procjena pacijenta ujedno korelira sa sposobnošću podnošenja neurokirurškog zahvata i postoperacijskog oporavka i prilagodbe. Osim toga, potrebno je i uzeti u obzir same simptome Parkinsonove bolesti, tremor, bradikineziju, sposobnost hoda, prethodno medikamentozno liječenje, uključujući odgovor na sadašnju terapiju te sam učinak nekih prethodnih kirurških zahvata. Proučavanjem literature od 1965 . godine do 2004. godine u bazi podataka Medline iz ukupno 574 članka u kojima se obrađuje tema DBS-a, povezanih s neruopsihologijske, neuropsihijatrijske, neuroslikovne i neurokirurške strane, primijenjena je prirodna podjela pitanja važnih za DBS prijeoperacijsku pripremu, operacijski protokol te postoperacijski oporavak i prilagodbu. Proučava- 
nje literature imalo je intenciju učiniti univerzalni obrazac pitanja kojima bi se procjenjivalo i pripremalo pacijente za DBS. Ono što se uistinu htjelo utvrditi je dobna granica u kojoj bi se izvršavala operacija, kao bitan prediktor za operaciju, pored svih drugih čimbenika, poput odgovora na levodopu, kognitivnog statusa i drugih komorbiditeta i treba li postojati ograničenje s obzirom na dob. Proučavalo se također treba li kognitivni status pored svih drugih komorbiditeta biti ograničavajući faktor, koja je uloga neuroslikovnih metoda u prijeoperacijskoj pripremi pacijenata, što ako dođe do egzacerbacije nakon DBS-a, što bi točno trebalo proučavati i koje alate koristiti, potreba za neuropsihologijskim i neuropsihijatriskim testiranjem i njegova uloga istoga, koji bi bio najbolji prediktor za operaciju, koja doza levodope bi trebala biti korištena za levodopa test te što bi uistinu bila prava i specifična indikacija za DBS i, na kraju, što pacijentu savjetovati i kako mu reći ako je ili nije potencijalni kandidat za DBS. Proučavanjem literature i članaka utvrdilo se kako se većini pacijenata koji boluju od Parkinsonove bolesti implantacija DBS-a vršila između 40. i 60. godina života, ali postoje izvješća u kojima se pacijentima i sa 75 i više godina izvršila implantacija DBS-a ${ }^{14}$. Unatoč različitim istraživanjima i dalje ne postoji konkretan podatak dobne granice do kad bi se pacijentima trebalo ugrađivati DBS, jer se korist DBS metode pokazala zadovoljavajuća u mlađoj, ali i u starijoj životnoj dobi. U sadašnjim preporukama ipak piše kako je idealna dob za primjenu DBS metode do 70 godina, iako se treba gledati individualno pacijenta i njegov kognitivni status. Bitna činjenica je također da ne postoje sustavna istraživanja koja bi jasno dala korelaciju između komorbiditeta pacijenata $\mathrm{s}$ ishodom ugradnje DBS-a i same operacije, jer je većina pacijenata u studijama, koji su imali komorbiditete, isključena za mogućnost DBS-a. Premalo je podataka i znanstvenih dokaza, koji također idu u prilog tome da bi bilo koja neuroslikovna metoda prijeoperacijski utjecala na isključivanje pacijenata. Samo nekolicina radova navodi kako bilo koja morfološka abnormalnost otkrivena neuroslikovnim metodama može biti „isključni“ faktor za DBS, osim blage atrofije mozga, dok suprotno tome pojedini radovi isključuju pacijente za DBS koji su imali bilo kakav oblik atrofije, leukoencefalopatije ili drugih abnormalnosti. Proučavanjem i istraživanjem literature nije se došlo do konkretnog zaključka što ako dođe do egzacerbacija simtopoma Parkinsonove bolesti nakon DBS-a. Prva istraživanja napominjala su da može doći do veće pojavnosti depresije ili sucidalnosti kod osoba koje su imale tešku depresiju prije operacije, ali novija istraživanja govore da nema razlike $u$ depresiji i suicidalnosti u odnosu na one koji se liječe medikamentozno. Štoviše, smatra se kako sam DBS pozitivno utječe na uklanjanje depresivnih epizoda koje su se pojavile u sklopu Parkinsonove bolesti. Zaključilo se također kako i testovi koji se vrše u prijeoperativnoj pripremi pacijenata za DBS nemaju posebnu prediktivnu vrijednost za utvrđivanje kognitivnog deficita, osim nekoliko testova kojima se dokazuje demencija, koja se smatra isključnim faktorom za DBS ${ }^{15}$. Međutim, činjenica je da ljudi koji obolijevaju od Parkinsonove bolesti imaju i različit stupanj obrazovanja, te to također može utjecati na ishod testiranja. Neuropsihologijskim i neuropsihijatrijskim testiranjem u prijeoperacijskoj pripremi utvrđeno je kako bi ipak pacijente $s$ akutnom depresivnom epizodom, suicidalnim namjerama, anksioznošću, apatijom, hipomanijom ili manijom trebalo isključiti iz daljnjeg postupka za DBS, barem do smirivanja simptoma ili potpune regulacije navedenih simtpoma medikamentoznim metodama. Novije studije govore u prilog tome kako pacijenti koji imaju niske doze lijeka zbog poremećaja spavanja uključene u svoju terapiju, ili ako imaju psihijatrijske simptome izazvane antiparkinsonicima, ne bi trebali biti isključeni kao potencijalni pacijenti za DBS. Ono što je sa sigurnošću potvrđeno iz svih istraživanja je važnost razmatranja omjera koristi i štete za pacijenta kod primijene DBS metode liječenja ${ }^{16,17}$.

Sve studije tijekom svojih istraživanja koje su proučavale DBS kao metodu liječenja Parkinsonove bolesti utvrdile su da je najbolji prediktor upravo odgovor na levodopu. Ranije je navedno kako još uvijek nije utvrđena doza koja bi bila granica za ocjenu ovog čimbenika, ali je ovaj čimbenik bitan u edukaciji pacijenta i obitelji o mogućnostima odgovora pacijentovih simptoma na DBS te također potrebi uzimanja lijekova unatoč primjeni 
DBS metode. Dobivenim rezultatima levodopa testa potrebno je objasniti pacijentu i obitelji realna očekivanja od operacije. Specifična indikacija za operaciju je u biti usko povezana s odgovorom pacijenta na levodopu i smanjenje motoričke onesposobljenosti u vidu akinezije, rigiditeta, hoda sitnim koracima, „OFF“ perioda te poboljšanje kvalitete života ${ }^{18}$.

U procesu su istraživanja kojima se želi odrediti vrijeme kada bi bilo idealno primijeniti terapiju DBS-om od nastupa bolesti. Većina dostupnih studija (posebno starijeg datuma) pokazuju da se DBS postavlja obično pacijentima u uznapredovanoj bolesti koji imaju dobar odgovor na levodopu s trajanjem bolesti 12 do 15 godina. Međutim, najnovije studije poput Earlystim pokazuju da ima opravdanja radi poboljšanja kontrole simptoma i kvalitete života oboljelih s Parkinsonovom bolesti, učiniti DBS i ranije (prosječno trajanje bolesti u studiji 7,5 godina). U literaturi se, također, spominje kako je isključni faktor u nekim državama, poput Sjedinjenih Američkih Država, zdravstveno osiguranje koje pacijent ne može pokrivati, što nije slučaj u Hrvatskoj gdje je zahvat pokriven sredstvima HZZO-a ${ }^{19}$. U tim zemljama neki pacijenti ne mogu pokriti najčešće niti troškove prijeoperacijske pripreme. Bitno je istaknuti kako prethodne operacije, pa čak i prethodno unilateralno postavljanje DBS-a, ne bi trebale biti kontraindikacija za postavljanje DBS-a na suprotnu stranu. Kao što je u prijašnjem poglavlju rečeno, dijagnoza idiopatske Parkinsonove bolesti mora biti sigurna da bi se razmatrao DBS, osim u istraživačke svrhe, kod traženja novih dijagnoza i bolesti koje bi se uspješno liječile DBS-om, kao i novih ciljnih mjesta, čemu svjedočimo stalnim napretkom neuroznanosti i tehničkih mogućnosti. Potpuna medicinska procjena je nužna za prijeoperacijsku pripremu pacijenata. Razlog tome je ponajviše tendencija Parkinsonove bolesti za daljnjom progresijom. Kao što je ranije navedeno, bitni su i komorbiditeti koji prate pacijenta. Jedan od problem su pacijenti koji imaju sve karakteristike za DBS, međutim, koriste antikoagulantnu i antitrombotsku terapiju zbog određenih kardijalnih komorbiditeta, koju bi trebalo prijeoperacijski ukinuti ili zamijeniti s niskomolekularnim heparinom, jer jedna od nuspojava kirurškog zahvata je poslijeoperacijsko krvarenje u vidu intracerebralnog hematoma, koje kod ovih pacijenata želimo izbjeći. Sve nesteroidne antireumatike treba obustaviti minimalno 7 do 10 dana prije operacije. Kod pacijenata s arterijskom hipertenzijom treba paziti na regulaciju tlaka. Poznato je kako je povišeni arterijski tlak rizični faktor za nastanak intracerebralnog krvarenja osobito tijekom stereotaktičkih postupaka. Noć prije samog postupka implantacije DBS-a lijekovi za Parkinsonovu bolest se ukidaju, kako bi se sami simptomi za vrijeme operacije jasnije uočili. Obitelj pacijenta, koji je kandidat za DBS, trebala bi biti spremna na cijeli postupak te bi trebala biti pacijentu podrška. Najbitnija je spremnost pacijenta na operaciju tijekom koje mora biti fizički i kognitivno sposoban biti budan i nekoliko sati imobiliziran. Štoviše, pacijenti trebaju biti spremni surađivati tijekom operacije. Bitnija komponenta su realna očekivanja od operacije, i ona pacijenta i ona obitelji, te spremnost i educiranost za održavanje implantiranog hardverskog sustava i da taj uređaj ne bi smio biti izložen magnetskom polju. Samo određeni aparati za magnetsku rezonanciju (MR), kao što su aparati funkcionalne magnetske rezonancije, mogu služiti za dijagnostiku kod tih pacijenata, a i samo neki neurostimulatori imaju odobrenje za ulazak u magnetsko polje ${ }^{20}$.

Nakon implantacije DBS-a pacijentima se, najčešće, život promijeni nabolje. Postaju manje ovisni o obitelji te se time i dinamika obitelji promijeni. Ne smiju zaboraviti činjenice koje im se objašnjavaju kod postavljanja indikacije, a to je da DBS nije lijek i ne zaustavlja bolest, te da se, s obzirom na to da bolest napreduje, učinak DBS-a može vremenom smanjivati ili se mogu razviti simptome na koje DBS nema zadovoljavajući učinak. Što se tiče bilateralnog postavljanja DBS-a, ponajviše to ovisi o pacijentovim simptomima, toleranciji na operacije i preferencijama tima. U Hrvatskoj i Europskoj uniji se obično odmah postavi bilateralno DBS kod Parkinsonove bolesti. Također, svaki kliničar trebao bi odmjeriti kod svog pacijenta dugogodišnju korist DBS-a i kvalitetu života koju to nosi ${ }^{21}$.

Često u procjeni, uz neurologa i neurokirurga, trebamo mišljenje psihologa, psihijatra, logopeda, fizijatra i fizioterapeuta. Ono što je najbitnije 
je u principu dobra procjena od strane multidisciplinarnog tima, koja obuhvaća procjenu motoričkih i nemotoričkih simptoma kod pacijenta te komorbiditeta koji mogu prevladati korist samog DBS-a ${ }^{22}$.

Dijagnoza, odgovor na levodopu, kognitivni status, psihijatrijski status, pristup njezi i očekivanja pacijenata ključni su elementi procesa odabira pacijenta za DBS. Ova se područja moraju adekvatno obraditi prije bilo kojeg kirurškog zahvata ${ }^{23}$.

\section{OPERACIJSKI PROTOKOL, PERIOPERATIVNE}

\section{POSTOPERATIVNE KOMPLIKACIJE}

Duboka mozgovna stimulacija najčešće se postavlja bilateralno. Pacijentima s esencijalnim tremorom, unilateralna duboka mozgovna stimulacija je dovoljna terapije bez dodatne medikamentozne terapije. Sam operacijski protokol postavljanja DBS-a sastoji se od dviju faza. Prva faza je postavljanje elektroda na za to predviđena mjesta u mozgu, koristeći se tehnikom tzv. „operacije pri svijesti - budna operacija“. Druga faza operacije je postavljanje žica samog uređaja u subkutane tunele od kranijalnog dijela do infraklavikularnog područja ${ }^{24}$. Dobar odabir pacijenata i ugradnja DBS sustava je prvi korak do uspješne terapije za pacijenta. Nakon završene operacije slijedi protokol po kojem se podešava hardverski sustav DBS uređaja. Programiranje se odnosi na niz postupaka kojim se odabiru najprikladniji parametri stimulacije koji za pacijenta imaju najveći terapijski učinak, bez nuspojava. Istovremeno s podešavanjem parametara stimulacije titrira se terapija antiparkinsonicima, gdje je često moguća redukcija antiparkinsonika i za više od 50 \%, a i individualna fizikalna rehabilitacija $^{25}$.

Unatoč malom brojem istraživanja, 5 - $16 \%$ pacijenata imaju komplikacije koje nastaju perioperativno ili postoperativno kod ugradnje DBS uređaja. Tijekom operacije 1.6 - $2.2 \%$ pacijenata ima respiratorne komplikacije, tj. komplikacije vezane za dišni put, iako su ranije anesteziološki obrađeni te svi parametri nisu ukazivali na mogućnost ovakvih komplikacija. Kod 3.2 \% pacijenata bilježi se nastanak embolizama uzrokovanih zrakom tijekom same ugradnje DBS-a. lako vrlo rijetko (ispod $1 \%$ pacijenata), pacijenti mogu tijekom stimulacije mozga koja nastaje ugradnjom DBS-a imati gene- ralizirane epileptičke napadaje; istraživanje tog uzroka je još uvijek u procesu. Posebno je potrebno istaknuti kako se kod pacijenata koji nisu na antikoagulantnoj terapiji mogućnost nastanka intrakranijalnog krvarenja pojavljuje u svega 0.5 $2.8 \%$ pacijenata. Nastanak postoperativnog delirijuma vrlo je rijetka pojava. Najčešće se veže za priležeće komplikacije, poput intrakranijalnog krvarenja, ili zbog primjene određenih anestezioloških lijekova. Činjenica je kako sam protokol izgleda vrlo jednostavno, međutim, bez prijeoperacijske pripreme i procjene pacijenta, anesteziološke službe i stručnog tima neurokirurških jedinica, upravo educiranih za takvu vrstu operacije, ovakva operacija ne bi se mogla izvršavati, a komplikacije se ne bi bilježile u tako malom postotku ${ }^{24-26}$.

\section{ZAKLJUČAK}

Uvidom u literaturu jasno se može zaključiti kako se motorički i nemotorički simptomi Parkinsonove bolesti mogu uspješno kontrolirati posebno u ranoj fazi bolesti. U uznapredovanoj fazi, ako je medikamentozna terapija nedostatna, postoje i drugi vidovi terapije, poput neurokirurške implantacije duboke mozgovne stimulacije. Unatoč činjenici kako svi pacijenti nisu idealni kandidati za DBS, trebamo inzistirati na tome da upravo oni koji jesu trebaju takvu terapiju i imati. Za dobar uspjeh DBS-a ključan je dobar odabir pacijenata, educirani multidisciplinarni tim, perioperativna priprema, vrstan neurokirurg za precizno postavljanje elektroda bez komplikacija te postoperativna rehabilitacija uz podešavanje stimulacijskih parametara i redukciju medikamentozne terapije, što je zadatak neurologa. Na ono što trebamo posebno misliti su prediktorni čimbenici, poput odgovora pacijenta na levodopu, edukacija pacijenata i obitelji o mogućnostima djelovanja DBS-a na pacijentove simptome i objasniti realna očekivanja od operacije. Prije same operacije bitna je fizička i kognitivna spremnost pacijenta na daljnje postupke. Daljnja istraživanja i napredak tehnologije, a i velike multicentrične studije, još će više unaprijediti indikacije, pripreme, DBS i njegove učinke na simptome i kvalitetu života oboljelih od Parkinsonove bolesti.

Izjava o sukobu interesa: Autori izjavljuju da ne postoji sukob interesa. 


\section{LITERATURA}

1. Longo LD, Fauci AS, Kasper LD, Hauser SL, Jameson JL, Loscalzo J. Harrison's Neurology in Clinical Medicine. $3^{\text {rd }}$ Edition. New York: Mc Graw Hill Education, 2013;333-30.

2. Simon RP, Aminoff MJ, Greenberg DA. Clinical Neurology. $10^{\text {th }}$ Edition. New York: Mc Graw Hill Education, 2018; 311-11.

3. Beiske AG, Loge $J H$, Ronningen A, Svensson E. Pain in Parkinson's disease: Prevalence and characteristics. Pain 2009;147:173-177.

4. DiMarzio M, Rashid T, Hancu I, Fiveland E, Prusika J, Gillogly $\mathrm{M}$ et al. Functional MRI Signature of Chronic Pain Relife From Deep Brain Stimulation in Parkinson Disease Patients. Neurosurgery 2019;0:1-7.

5. Parkinson's disease: Hope through research. National Institute of Neurological Disorders and Stroke. [cited 2019 Dec 18] Available from: https://www.ninds.nih.gov/Disorders/Patient-Caregiver-Education/Hope-Through-Research/Parkinsons-Disease-Hope-Through-Research.

6. Weaver FM, Follett K, Stern M, Hur K, Harris C, Marks WJ et al. Bilateral Deep Brain Stimulation vs Best Medical Therapy for Patients With Advanced Parkinson Disease. JAMA 2009;301:63-73.

7. Lang $A E$, Widner H. Deep Brain Stimulation for Parkinson's Disease: Patient Selection and Evaluation. Movement Disorders 2002;3:94-101.

8. Welter ML, Houeto JL, Montcel ST, Mesnage V, Bonnet AM, Pidoux B et al. Preoperative Clinical Factors Predict the Effects of Subthalamic Stimulation in Parkinson's Disease (PD). Neurology 2001;56:146.

9. Custozzo Amanda, DiMarzio Marisa, Pilitsis G. Julie. Addressing Parkinson Disease-Related Pain with Deep Brain Stimulation. World Neurosurgery 2020;135:381382.

10. Lang $A E$, Houeto JL, Krack P, Kubu C, Lyons KE, Moro E et al. Deep Brain Stimulation: Preoperative Issues. Movement Disorders 2006;14:171-196.

11. Katz M, Kilbane C, Rosengard J, Alterman RL, Tagliati M. Reffering Patients for Deep Brain Stimulation. An Improving Practice. Arch Neurol 2011;68:1027-1032.

12. Silberstein P, Bittar RG, Boyle R, Stell R, Watson P. Deep brain stimulation for Parkinson's disease: Australian refferal guidelines. Journal of clinical neuroscience 2009; 16:1001-1008.

13. Okun MS,Tagliati $M$, Pourfar $M$, Fernandez $H H$, Rodriguez RL, Alterman RL et al. Management of Referred Deep Brain Stimulation Failures: A Retrospective Analysis From 2 Movement Disorders Centers. Arch Neurol 2005; 62:1250-5.
14. Machado A, Rezai AR, Kopell BH, Gross RE, Sharan AD, Benabid AL. Deep Brain Stimulation for Parkinson's Disease: Surgical Technique and Perioperative Management. Movement Disorder 2006;14:247-258.

15. Schapira HVA, Chaudchuri KR, Jenner P. Non-motor features of Parkinson disease. Nature reviews Neuroscience 2017;18:435-450.

16. Schuepbach WM, Rau J, Knudsen K. Neurostimulation for Parkinson's disease with early motor complications. N Engl J Med 2013;368:610-622.

17. Schroeder U, Kuehler A, Hennenlotter A, Haslinger B, Tronnier VM, Krause $M$ et al. Facial expression recognition and subthalamic nucleus stimulation. J Neurol Neurosurg Psychiatry. 2004;75:648-650.

18. Kleiner-Fisman G, Fisman DN, Sime E, Saint-Cyr JA, Lozano $A M$, Lang $A E$. Long-term follow up of biltareal deep brain stimulation of the subthalamic nucleus in patient with advanced Parkinson disease. J Neurosurg 2003;99: 489-495.

19. Hlk.hr[Internet]. Zagreb: Glasilo Hrvatske liječničke komore, Godina XV, broj 148, travanja 2016 [cited 2020 April 28]. Available from: https://www.hlk.hr/EasyEdit/ UserFiles/Inpdf/148/In-148web.pdf.

20. Fiveland E, Madhavan R, Prusik J, Linton R, Dimarzio M, Ashe J et al. EKG-Based Detection of Deep Brain Stimulation in fMRI Studies. Magn Reson Med 2018;79: 2432-2439.

21. Kocabicak E, Temel Y, Höllig A, Falkenburger B, Tan SKH. Current perspectives on deep brain stimulaton for severe neurological and psychiatric disorders. Neuropsychiatric Disease and Treatment 2015;11:1051-1066.

22. Marras C, Chaudhuri RK. Nonmotor Features of Parkinson's Disease Subtypes. Movement Disorder 2016;31: 1095-1022.

23. Rodriguez R, Fernandez H, Haq I, Okun M. Pearls in Patient Selection for Deep Brain Stimulation. The Neurologist 2007;13:253-260.

24. Bailine S, Kremen N, Kohen I, Linder H, Schwartz GJ, Mogilner AY et al. Bitemporal Electroconvulsiove Therapy for Depression in a Parkinson Disease Patient With a Deep-Brain Stimulator. J ECT 2008;24:171-172.

25. UpToDate [Internet]. Venkatraghavan L, Pasternak JJ, Crowley M.: Anesthesia for patient who undergo deep brain stimulator implantation c2020 [cited 2020 April 11]. Available from: https://www.uptodate.com/contents/anesthesia-for-patients-who-undergo-deep-brainstimulator-implantation.

26. Miocinovic S, Somayajula S, Chitnis S. History, Applications, and Mechanisms od Deep Brain Stimulation. Jama Neurol. 2013;70:163-171. 